\title{
Detection of Bone Metastases in Initial Staging of Orbital Embryonal Rhabdomyosarcoma by Fluorodeoxyglucose Positron Emission Tomography/Computed Tomography
}

\author{
Orbital Embriyonel Rabdomiyosarkomun Illk Evrelemesinde Kemik Metastazlarının \\ Florodeoksiglukoz Pozitron Emisyon Tomografi/Bilgisayarlı Tomografi ile Saptanması
}

\author{
Pelin Ozcan Karal, Gonca Kara Gedik1, Oktay Sari2 \\ I Selcuk University Selcuklu Medical Faculty, Department of Nuclear Medicine, Konya, Turkey \\ 2Selcuk University Meram Medical Faculty, Department of Nuclear Medicine, Konya, Turkey
}

\begin{abstract}
Rhabdomyosarcoma is the most common form of soft tissue sarcoma in young children. In soft tissue sarcomas, isolated metastases are seen in the lung, soft tissue, and bone. The optimal management of these tumors depends on the site, size, and grade of the local growth, and accurate staging of the disease when first seen. Although detection of the primary site of disease is usually accomplished well with conventional techniques, the performance of fluorodexyglucose (FDG) positron emission tomography/computed tomography (PET/CT) may be useful to determine metastases that are not clinically evident. We describe a case of early detection of distant metastases by FDG PET/CT in a young patient diagnosed with orbital embryonal rhabdomyosarcoma. (MIRT 2011; 20: 34-5)

Key words: Rhabdomyosarcoma; FDG-PET/CT; initial staging; bone metastases
\end{abstract}

\section{Özet}

Rabdomiyosarkom çocukluk çağında en sık görülen yumușak doku sarkomudur. Yumuşak doku sarkomlarında, izole metastazlar akciğerde, yumuşak dokuda ve kemikte görülür. Bu tümörlerin optimum değerlendirilmesinde primer tümörün bölgesi, boyutu, lokal yayılımı ve ilk tanı anında tam evrelemesi oldukça önemlidir. Primer hastalık bölgesinin tanısı çoğunlukla konvansiyonel görüntüleme teknikleri ile tanımlanmasına rağmen, F 18 FDG PET/BT klinik olarak henüz belirgin olmayan metastazların saptanmasında yararı olabilir. Bu yazıda orbital bölgede embriyonel rabdomiyosarkom tanısı alan genç bir hastada F 18 FDG PET/BT ile uzak metastazların erken dönemde tespit edilmesi sunulmuștur. (MIRT 201 1; 20: 34-5)

Anahtar kelimeler: Rabdomiyosarkom; FDG PET/BT; ilk evreleme; kemik metastazları

\section{Case Report}

A 17-year-old boy presented to our department with dyspnea and diplopia lasted for approximately one month. MRI demonstrated $6 \times 4 \times 4 \mathrm{~cm}$ mass with irregular contour in the orbital region. On MRI, one left cervical and one submandibular lymph node were also detected. Embryonal rhabdomyosarcoma (RMS) was diagnosed by biopsy. To better define the lesion prior to surgery and in a search for distant metastases, we performed a combined FDG PET/CT whole-body scan. PET/CT revealed the primary lesion with irregular contours. Maximum calculated standardized uptake value (SUVmax) of the lesion was 9.82 PET/CT also demonstrated bilateral cervical and submandibular lymph nodes showing intense FDG accumulation (SUVmax 9.44). Additionally, there were pathological accumulations in pelvic 
bones, bilateral proximal femora, bilateral humeri, scapula, sternum, clavicles, ribs, and vertebrae (Figure 1). The patient could not undergo complete resection because of the local invasion on computed tomography and magnetic resonance imaging and distant metastases. Chemoradiotherapy was initiated. In our patient, FDG-PET combined with simultaneous low-dose CT transmission tomography, permitted the detection of distant metastases that was not clinically evident. PET/CT also showed pathological contralateral cervical lymph nodes that were not seen on MRI. The patient was upstaged on FDG PET/CT. The orbit is one of the most common sites for RMS. Most of the patients with orbital sarcoma present with localized disease. Patients presenting metastatic disease at

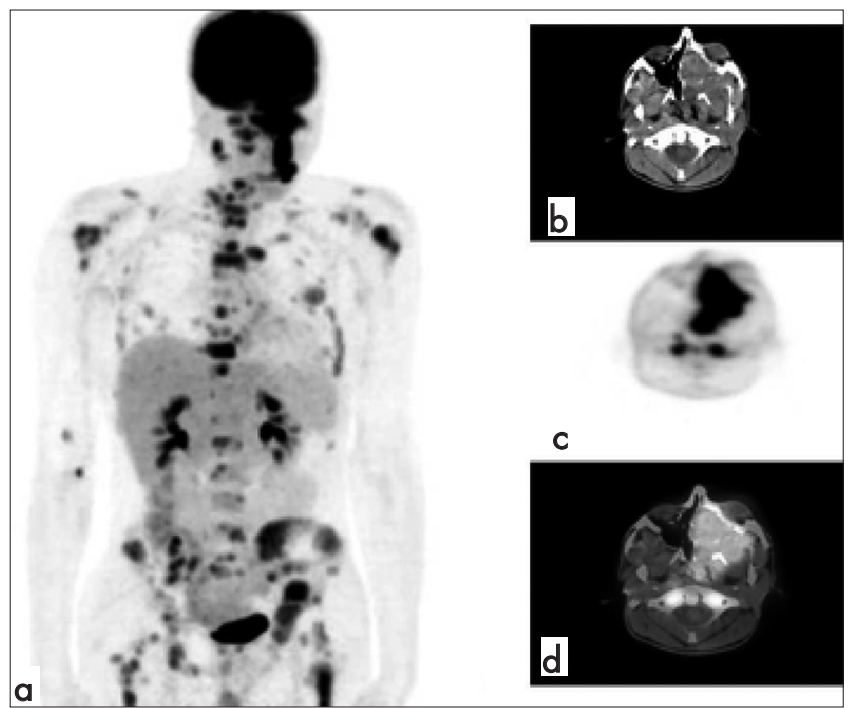

Figure 1. MIP image (a) and transaxial images $(b, c, d)$ of PET/CT revealed the primary lesion (SUVmax: 9.82) and bilateral cervical lymph nodes (SUVmax 9.44), pelvic bones, bilateral proximal femora, bilateral humeri, scapula, sternum, clavicles, ribs, and vertebrae initial diagnosis are uncommon. However, bone marrow involvement counts among the most common metastases, especially in the presence of extensive local invasion (1). Embryonal RMS is the most common histology in patients with non-metastatic orbital sarcoma. In Stage 4 cases, embryonal RMS was found in about half of the cases (2). There are few reports about the efficacy of FDG PET/CT in the localization and detection of soft tissue sarcomas $(3,4)$. In a study by Tateishi et al (5), 11 of the 35 patients had distant metastases detected by FDG PET/CT, which were not identified by conventional radiologic evaluation. FDG PET/CT was found more accurate than conventional imaging regarding clinical staging and re-staging of patients with rhabdomyosarcomas. Although, overall likelihood of bone involvement is low in orbital embryonal RMS at initial diagnosis, FDG PET/CT may be useful in patients with a higher likelihood of distant metastases.

\section{References}

1. Huh WW, Anderson JR, Rodeberg D, Teot L, Yock T, Raney RB. Orbital Sarcoma With Metastases at Diagnosis: A Report From the Soft Tissue Sarcoma Committee of the Children's Oncology Group. Pediatr Blood Cancer 2010;54:1045-1047.

2. Kodet R, Newton WA Jr, Hamoudi AB, Asmar L, Wharam MD, Maurer HM. Orbital rhabdomyosarcomas and related tumors in children: Relationship of morphology to prognosis-An Intergroup Rhabdomyosarcoma Study. Med Pediatr Oncol 1997;29:51-60.

3. McCarville MB, Christie R, Daw NC, Spunt SL, Kaste SC. PET/CT in the evaluation of childhood sarcomas. AJR Am J Roentgenol 2005;184:1293-1304.

4. Ben Arush MW, Bar Shalom R, Postovsky S, Militianu D, Haimi M, Zaidman I, Israel O. Assessing the use of FDG-PET in the detection of regional and metastatic nodes in alveolar rhabdomyosarcoma of extremities. J Pediatr Hematol Oncol 2006;28:440-445.

5. Tateishi U, Hosono A, Makimoto A, Nakamoto $Y$, Kaneta T, Fukuda H, Murakami K, Terauchi T, Suga T, Inove T, Kim EE. Comparative study of FDG PET/CT and conventional imaging in the staging of rhabdomyosarcoma Ann Nucl Med 2009;23:155-161. 